\title{
INTRODUKSI MOCAF (MODIFIED CASSAVA FLOUR) SEBAGAI PENDUKUNG DIVERSIFIKASI DAN KETAHANAN PANGAN MASYARAKAT DAWIS 1 RT 03/24 JEBRES
}

\author{
Novian Wely Asmoro, Sri hartati, dan Catur Budi Handayani \\ Program Studi Teknologi Hasil Pertanian, Fakultas Pertanian, Universitas Veteran Bangun Nusantara \\ Jl. Letjen S. Humardhani No. 1 Sukoharjo, Email: novianwelyasmoro@gmail.com \\ E-mail: novianwelyasmoro@gmail.com
}

\begin{abstract}
ABSTRAK.Pemahaman dan kepedulian masyarakat terkait diversifikasi pangan sangat penting dan memberikan kontribusi bagi ketahanan pangan masyarakat khususnya keluarga dalam lingkup kecil, terlebih lagi pada kondisi pandemi Covid-19 yang terjadi saat ini. Dasawisma 1 (Dawis 1) RT 03/24 Kelurahan Jebres Kecamatan Jebres Surakarta merupakan lingkup organisasi kecil tingkat RT yang menjadi mitra kegiatan pengabdian masyarakat. Tujuan kegiatan pengabdian adalah pengenalan tepung Mocaf sebagai salah satu cara untuk meningkatkan pemahaman masyarakat mengenai diversifikasi dan ketahanan pangan. Metode kegiatan yang dilakukan melalui empat tahap antara lain: (1). sosialisasi diversifikasi pangan dan ketahanan pangan; (2). penyuluhan dan pemberian materi tepung Mocaf dan olahannya; (3). introduksi praktek mandiri olahan produk mocaf; (4). evaluasi kegiatan penyuluhan dan pelatihan yang telah dilakukan melalui pembandingan hasil pretest dan postest. Kegiatan dinyatakan berhasil apabila terjadi peningkatan pemahaman peserta sebesar $>75 \%$. Kegiatan pengabdian kepada masyarakat telah berjalan dengan baik dan diikuti $80 \%$ mitra yang menjadi sasaran. Berdasarkan evaluasi hasil kegiatan menunjukan adanya peningkatan pengetahuan bagi masyarakat mitra yaitu rata-rata peningkatan pemahanan sebesar $77,5 \%$.
\end{abstract}

Kata kunci: Diversifikasi pangan; Introduksi; tepung Mocaf

ABSTRACT. Public understanding and concern regarding food diversification is very important and contributes to the food security of the community, especially small families in the current conditions of the Covid-19 pandemic. Dasawisma 1 (Dawis 1) RT 03/24 Jebres Subdistrict Jebres Surakarta is the scope of a small level organization that is a partner in this service activity. The purpose of this community service activity is the introduction of Mocafflour as a way to increase public understanding of diversification and food security. The method of activities carried out through four stages, among others: (1). socialization of food diversification and food security; (2). counseling and provision of materials for Mocaf flour and its processed products; (3). introduction of independent practice of processed mocaf products; (4). evaluation of counseling and training activities that have been carried out by comparing the results of the pretest and posttest. The activity is declared successful if there is an increase in participants' understanding of $>75 \%$. Community service activities have been going well and were followed by $80 \%$ of the targeted partners. Based on the evaluation of the activity results, it shows an increase in knowledge for the partner community, namely an average increase in understanding of $77.5 \%$.

Keywords: Food diversification; Introductions; Mocafflour

\section{PENDAHULUAN}

Mocaf (Modified Cassava Flour) merupakan modifikasi tepung singkong melalui proses fermentasi menggunakan mikroorganisme (Darmawan et al., 2013; Noor et al., 2018; Tandrianto et al., 2014). Proses fermentasi menyebabkan perubahan karakteristik fisik maupun kimiawi tepung singkong. Perubahan karakteristik fisik pada mocaf antara lain peingkatan daya ikat air, daya kembang, sineresis, dan sifat morfologi granula pati (Putri et al., 2018). Selain itu, mocaf juga mengalami peningkatan kandungan protein (Hersoelistyorini et al., 2015; Tandrianto et al., 2014). Perubahan karakteristik tersebut maka mocaf dapat dimanfaatkan sebagai bahan baku olahan produk yang lebih bervariasi. Tepung mocaf banyak dimanfaatkan sebagai substitusi tepung terigu pada pembuatan produk mie, roti kering dan roti basah, makanan ringan (snack), dan beberapa substitusi produk lain (Abbas et al., 2010; Asmoro et al., 2017; Asmoro \& Afriyanti, 2020; Assalam et al., 2019; Darmawan et al., 2013; Herawati et al., 2018; Koswara, 2009; Rosmeri \& Monica, 2013).
Pemanfaatan tepung mocaf mendorong diversifikasi dan ketahanan pangan bagi masyarakat karena bahan baku yang digunakan berasal dari singkong dalam hal ini merupakan sumber daya lokal. Beberapa penelitian, tepung mocaf dapat digunakan untuk substitusi tepung terigu berkisar $20-100 \%$ terutama pada beberapa produk roti dan biskuit (Arsyad, 2016; Bayhaqi \& Bahar, 2016; Nur'utami et al., 2020). Pengetahuan dan pemahaman untuk memanfaatkan tepung mocaf sebagai produk olahan pangan harus ditingkatkan di masyarakat. Melalui intruduksi yang mencakup pengenalan dan pemanfaatan produk tepung mocaf kepada masyarakat, khususnya ibu-ibu diharapkan dapat memberikan dorongan inisiasi dan kontribusi bagi peningkatan diversifikasi pangan di masyarakat

Dasawisma 1 (Dawis 1) di RT 03/24 Kelurahan Jebres Kecamatan Jebres Surakarta merupakan salah satu dawis yang memiliki jumlah Kepala Keluarga (KK) 15 rumah. RT 03/24 merupakan wilayah RT yang berada di pinggir perkotaan di Kecamatan Jebres memiliki latar belakang pendidikan dan pekerjaan 
masyarakat yang berbeda-beda. Sebagai salah satu organisasi masyarakat yang aktif di setiap Dawis memiliki PKK Dawis yang mewadahi kegiatan para wanita/ibu-ibu khususnya di RT 03/24. Anggota yang terlibat dalam kegiatan PKK tersebut berjumlah 15 orang, dengan kegiatan yang rutin dilakukan satu bulan sekali adalah rapat dan arisan. PKK dawis 1 saat ini diketuai oleh Ibu Tutik, merupakan salah satu sarana yang dimanfaatkan untuk pemberdayaan masyarakat khususnya melalui lingkup kecil keluarga. Informasi dan pengetahuan akan lebih mudah tersampaikan langsung kepada anggota yang terlibat dalam kegiatan PKK khususnya ibu-ibu dan harapannya langsung dapat teraplikasikan di dalam lingkup keluarga.

Berdasarkan informasi yang diperoleh masyarakat khususnya RT 03/24 belum mengenal tepung Mocaf, dan belum memahami bagaimana diversifikasi pangan keterkaitannya dengan ketahanan pangan. Kondisi saat ini khususnya, pola konsumsi pangan telah mengalami banyak perubahan sehingga masyarakatharus semakin peduli dengan diversifikasi pangan dan meningkatkan ketahanan pangan keluarga. Permasalahan mitra berdasarkan analisis situasi yang telah dijabarkan, dapat diidentifikasi permasalahan sebagai berikut: 1). Kondisi saat ini terjadi perubahan pola konsumsi dimasyarakat dan terjadi pengaruh terhadap ketahanan pangan masyarakat. 2). Kebutuhan untuk meningkatkan pemahaman kepada masyarakat terkait diversifikasi dan ketahanan pangan. 3). Mitra belum memiliki pengetahuan mengenai tepung mocaf dan belum memiliki keterampilan pengolahan tepung mocaf menjadi produk pangan sebagai salah satu upaya diversifikasi pangan. Berdasar uraian permasalahan tersebut, pelaksanaan introduksi dan penyuluhan terkait diversifikasi pangan dan tepung mocaf sebagai salah satu komoditas lokal yang bisa dikembangkan sebagai produk olahan pangan. Mitra diharapkan dapat meningkatkan soft skill dan hard skill dalam diversifikasi pangan.

\section{METODE}

Kegiatan pengabdian kepada masyarakat dilaksanakan selama 3 bulan (Juli-September 2020). Mitra berlokasi di Dawis 1, RT 03/24 Jebres, Kecamatan Jebres, Surakarta. Jumlah mitra yang terlibat sebanyak 15 orang merupakan pengurus dan anggota aktif Dawis 1 RT 03/24.

Metode pelaksanaan menggunakan pola door to door, pemaparan materi melalui poster dan brosur, serta praktek dan pengenalan produk dalam kelompok kecil. Upaya pemecahan masalah (solusi) yang digunakan dalam pelaksanaan kegiatan ini meliputi langkah-langkah yang ditampilan pada Gambar 1 .

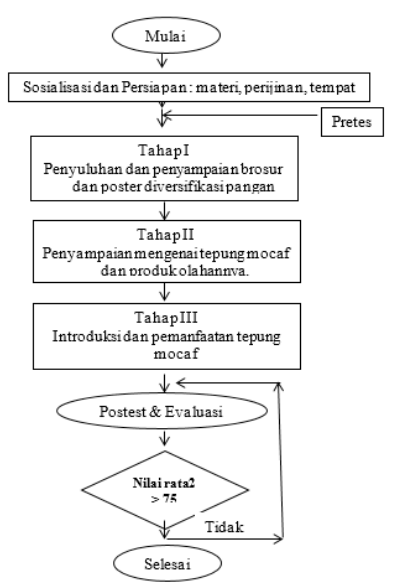

Gambar 1. Tahapan Metode Kegiatan Pengabdian

Evaluasi dilakukan menggunakan metode test sebelum program dimulai (pre test) dan sesudah program dimulai (post test). Point pertanyaan antara lain meliputi bagaimana pola makan dan konsumsi pangan, pemahaman dan penerapan diversifikasi pangan, dan pemahaman mengenai tepung mocaf serta produk olahannya. Setiap jawaban dinilai benar atau salah sesuai dengan jawaban peserta. Nilai peserta program adalah jumlah total dari keseluruhan jawaban benar. Nilai keseluruhan dari peserta selanjutnya dirata-rata untuk mendapatkan nilai rata-rata pelaksanaan program. Evaluasi terhadap indikator keberhasilan program, bila skor post test memiliki nilai $\geq 75 \%$.

\section{HASIL DAN PEMBAHASAN}

\section{Penyuluhan dan penyampaian pentingnya diversifikasi pangan}

Penyuluhan telah dilaksanakan tim pada tanggal 20-25 Juli 2020 antara Pukul 15.00-17.00 di rumah mitra wilayah Dawis 1 RT 3/24 Jebres Surakarta. Jumlah mitra sasaran yang terlibat sebanyak 12 rumah tangga dilingkungan Dawis 1, hal ini menunjukan $80 \%$ peserta target mitra yang berjumlah 15 di Dawis 1 telah terpenuhi. Materi yang disampaikan melalui penjelasan poster dan brosur terkait dengan: a). Pentingnya asupan sayuran dan buah. Hal tersebut mendorong masyarakat mitra agar lebih peduli dalam penyediaan kecukupan sayuran dan buah di rumah tangga pada konsumsi harian. b). Menjaga gizi dan gaya hidup sehat keluarga; hal ini mencakup konsumsi pangan yang bervasiasi, bergizi dan seimbang, serta mengurangi konsumsi gula, garam, lemak dan penyedap rasa. c). Keamanan pangan pada penanganan produk pangan rumah tangga. Hal tersebut melingkupi pemilihan bahan makanan yang sehat dan aman.

Secara umum, materi yang disampaikan tersebut sebagai kegiatan awal untuk membangun kepedulian terhadap pola konsumsi yang mengedepankan pangan sehat, bergizi dan beragam. Pola ini dapat dipenuhi 
dengan meningkatkan konsumsi produk pangan yang bersumber dari bahan lokal salah satunya adalah tepung mocaf. Bahan pangan lokal harus dikembangkan menjadi produk-produk yang lebih beragam dan bervariasi sehingga mudah diterima dan dijangkau masyarakat (Dewi \& Ginting, 2012).

Hasil pendataan menunjukan bahwa $90 \%$ atau mayoritas mitra memiliki umur produktif dibawah 50 tahun dengan pendidikan mayoritas hanya SMP dan SD (60\%) dan $45 \%$ berstatus murni sebagai Ibu rumah tangga yang tidak bekerja di luar rumah. Secara lengkap data dapat dilihat pada grafik Gambar 2

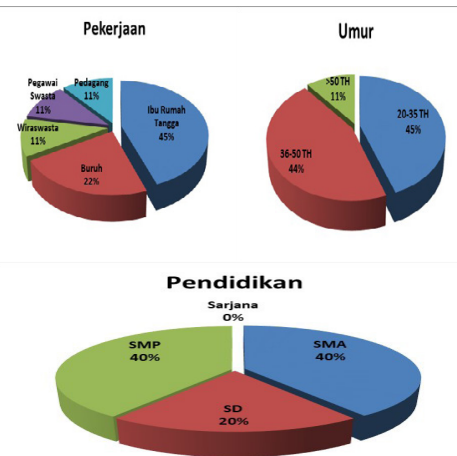

Gambar 2. Grafik Data Kondisi Mitra

Data kuisioner awal menunjukan kondisi pemahaman masyarakat mitra terhadap diversifikasi pangan sangat rendah, hanya $20 \%$ yang mengetahui tentang bagaimana diversifikasi pangan yaitu terkait dengan penganekaragaman pangan. Padahal saat ini, kondisi pandemi Covid-19 yang sedang terjadi menuntut masyarakat untuk mengembangkan pola konsumsi yang baik serta memperhatikan pangan dari segi keamanan, kecukupan gizi dan ketahanan pangan/penyediaan pangan yang mencukupi. Sebanyak 90\% keluarga di Dawis 1 menyatakan bahwa pola makan dan konsumsi pangan saat ini berubah, dipengaruhi oleh kondisi pendapatan keluarga dan situasi pandemi Covid-19. Menurut penelitian Hapsari et al., (2020), perubahan pola konsumsi masyarakat selama pandemi Covid 19 terjadi karena adanya peningkatan kesadaran masyarakat terhadap kesehatan. Data secara rinci dapat dilihat pada Gambar 3.

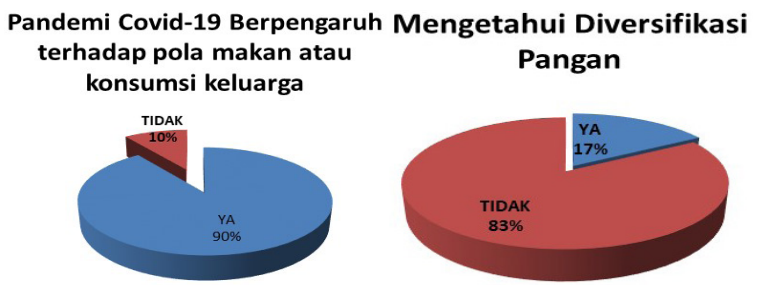

Gambar 3. Grafik Kuisioner Awal Mitra (Konsumsi Keluarga dan Pemahaman Diversifikasi Pangan)

Penyuluhan Tepung Mocaf dan Produk Olahannya

Pelaksanaan kegiatan dilakukan pada minggu pertama bulan Agustus 2020. Tim pengabdi bersilaturahmi, mendatangi dan menyampaikan materi terkait dengan tepung mocaf dan produk olahannya menggunakan media poster grafis pada setiap rumah di Dawis 1 RT 3/24 Jebres. Kegiatan ini dimaksudkan untuk memberikan wawasan dan pengetahuan mengenai produk tepung mocaf yang merupakan hasil diversifikasi pangan dari bahan baku singkong diproses menjadi tepung termodifikasi sehingga disebut sebagai tepung Mocaf (Modified Cassava Flour) (Darmawan et al., 2013; Noor et al., 2018; Tandrianto et al., 2014). Tepung Mocaf dapat digunakan untuk pengolahan produk pangan yang variatif sebagai pengganti peran tepung terigu. Peningkatan nilai gizi pada produk olahan tepung mocaf dapat divariasikan dengan penambahan komponen lain misalnya sayuran dan protein kacang-kacangan atau hewani (Hasrini et al., 2021; Unayah et al., 2020) Berdasarkan data kuisioner yang diisi oleh mitra pengabdian, 100\% mitra pengabdian belum mengetahui mengenai tepung Mocaf dan pemanfaatannya.

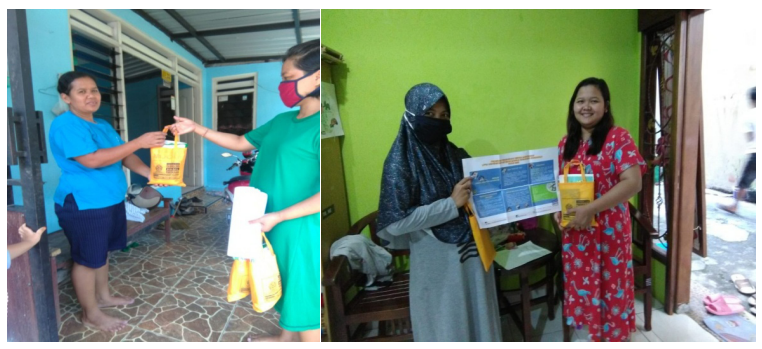

Gambar 3. Kegiatan Penyuluhan pada Peserta

Introduksi dan Pemanfaatan Tepung Mocaf

Introduksi dan pengenalan tepung Mocaf kepada seluruh mitra pengabdian yang menjadi sasaran di Dawis 1 RT 03/24. Kepada 12 mitra tersebut, dibagikan tepung Mocaf sekaligus dikenalkan mengenai asal tepung Mocaf dan penggunaannya. Dari 12 mitra, belum ada yang mengenal tepung Mocaf, hal tersebut ditunjukan dari 100\% mitra menjawab tidak tahu mengenai tepung tersebut. Kegiatan introduksi dan pengenalan tepung Mocaf dapat dilihat pada Gambar 4.

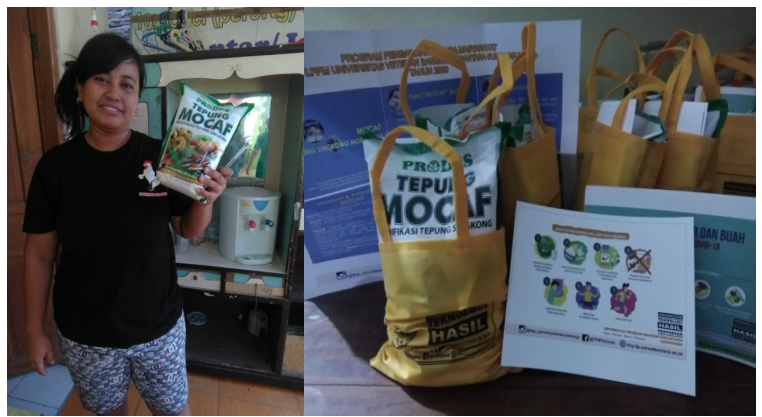

Gambar 4. Proses Introduksi Tepung Mocaf Kepada Mitra Sasaran Pengabdian

Berdasarkan evaluasi melalui kuisioneryang telah disebarkan kepada mitra sasaran pengabdian, sebanyak 90\% tidak mengetahui tepung mocaf dan belum pernah menggunakannya sebagai produk olahan pangan. Hal tersebut juga sebanding dengan pengetahuan masyarakat mengenai diversifikasi pangan yang sangat rendah. Hasil evaluasi disajikan pada Tabel 1. 
Tabel 2. Tabel Evaluasi Introduksi Tepung Mocaf Kepada Mitra

\begin{tabular}{lcc}
\hline \multicolumn{1}{c}{ Kegiatan } & $\begin{array}{c}\text { Pemahaman tentang } \\
\text { Diversifikasi Pangan }\end{array}$ & $\begin{array}{c}\text { Pemahaman } \\
\text { tentang Tepung } \\
\text { Mocaf }\end{array}$ \\
\hline $\begin{array}{l}\text { Sebelum } \\
\text { Kegiatan }\end{array}$ & $25 \%$ & $20 \%$ \\
$\begin{array}{l}\text { Sesudah } \\
\text { Kegiatan }\end{array}$ & $100 \%$ & $100 \%$ \\
Peningkatan & $\mathbf{7 5 \%}$ & $\mathbf{8 0 \%}$ \\
Rata-rata & & $\mathbf{7 7 , 5 \%}$ \\
\hline
\end{tabular}

Secara umum, hasil kegiatan penyuluhan dan pemberian materi kepada mitra mendapatkan respon yang sangat baik. Pada kondisi pandemi Covid-19 yang sedang berlangsung saat ini, memaksa untuk melakukan perubahan metode penyuluhan dan penyampaian materi pada kegiatan pengabdian. Dari 15 Target mitra yang menjadi sasaran pengabdian, 12 peserta (80\%) dapat mengikuti dengan baik kegiatan pengabdian masyarakat $20 \%$ yang tidak mengikuti karena kendala kesibukan dan usia yang sudah tidak bisa mengikuti materi pengabdian.

Kegiatan ini dapat memberikan manfaat kepada mitra terkait dengan pentingnya diversifikasi pangan dan pola konsumsi pangan yang baik. Selain itu, memberikan wawasan dan keterampilan kepada mitra untuk pemanfaatan tepung Mocaf. Hasil evaluasi menunjukan kegiatan ini memberikan peningkatan pemahaman masyarakat mitra (terkait dengan diversifikasi pangan dan tepung Mocaf) sebesar $77,5 \%$.

\section{SIMPULAN}

Kesimpulan dari kegiatan pengabdian kepada masyarakat yaitu Pelaksanaan kegiatan pengabdian kepada masyarakat kepada mitra Dawis 1 RT 03/24 telah berjalan dengan baik, diikuti $80 \%$ dari mitra yang menjadi sasaran. Pelaksanaan pengabdian memberikan wawasan dan pengetahuan kepada masyarakat terkait diversifikasi dan introduksi tepung mocaf. Intoduksi tepung mocaf memberikan peningkatan pengetahuan masyarakat mitra sebesar $77,5 \%$ dari nilai awal hasil pretest.

\section{UCAPAN TERIMAKASIH}

Terimakasih kamiucapkan kepada LPPMUniversitas Veteran Bangun Nusantara Sukoharjo yang telah memberikan pendanaan kegiatan pengabdian kepada masyarakat dengan skema PMKBI Tahun 2020.

\section{DAFTAR PUSTAKA}

Abbas, K. A., K. Khalil, S., \& Meor Hussin, A. S. (2010). Modified Starches and Their Usages in Selected Food Products: A Review Study. Journal of Agricultural Science, 2(2). https:// doi.org/10.5539/jas.v2n2p90
Arsyad, M. (2016). Pengaruh Penambahan Tepung Mocaf Terhadap Kualitas Produk Biskuit. Jurnal Agropolitan, 3(3), 52-61.

Asmoro, N. W., \& Afriyanti. (2020). Teknologi Pengolahan Mocaf (Andriyanto (ed.)). CV. Penerbit Lakeisha.

Asmoro, N. W., Hartati, S., \& Handayani, B. (2017). Karakteristik Fisik dan Organoleptik Produk Mocatilla Chips dari Tepung Mocaf dan Jagung. Jurnal Ilmu Pangan Dan Hasil Pertanian, 1(1), 63-70.

Assalam, S., Asmoro, N. W., Tari, A. I. N., \& Hartati, S. (2019). Pengaruh Ketebalan Irisan Chips Singkong dan Lama Fermentasi Terhadap Sifat Fisiko Kimia Tepung Mocaf (Modified Cassava Flour). AGRISAINTIFIKA: Jurnal Ilmu-Ilmu Pertanian, 3(1), 31. https://doi. org/10.32585/ags.v3i1.554

Bayhaqi, A., \& Bahar, A. (2016). Pengaruh Subtitusi Tepung Moncaf (Modified Cassava Flour) dan Penambahan Puree Wortel (Daucus Carota L.) terhadap Hasil Jadi Pizza. Jurnal Tata Boga, 5(1). https:/jurnalmahasiswa. unesa.ac.id/index.php/jurnal-tata-boga/ article/view/18411

Darmawan, M. R., Andreas, P., Jos, B., \& Su, S. (2013). Modifikasi Ubi Kayu Dengan Proses Ferermentasi Menggunakan Starter Lactobacillus Casei Untuk Produk Pangan. Jurnal Teknologi Kimia Dan Industri, 2(4), 137-145.

Dewi, G. P., \& Ginting, A. M. (2012). Antisipasi Krisis Pangan Melalui Kebijakan Diversifikasi Pangan. Jurnal Ekonomi \& Kebijakan Publik, 3(1), 65-78.

Hapsari, L. A., Astuti, A. P., \& Praswati, A. N. (2020). Konsumsi Makanan dan Olahraga selama Pandemi Covid 19. The 12th University Research Colloqium 2020 Universitas 'Aisyiyah Surakarta, 154-161.

Hasrini, R. F., Aviana, T., \& Khoiriyah, A. (2021). Fortification of Modified Cassava Flour (Mocaf) Cookies with Rich Nutrition Vegetable Powder. E3S Web of Conferences, 232, 3-10. https://doi. org/10.1051/e3sconf/202123203009

Herawati, B. R. A., Suhartatik, N., \& Widayanti, Y. A. (2018). Mocaf (Modified Cassava Flour) Cookies with the Addition of Cinnamon Powder (Cinnamomun burmanni). Jurnal Teknologi Dan Industri Pangan, 3(1), 33-40.

Hersoelistyorini, Dewi, W. ikanastri, SintoKumoro, S., \& Cahyo, A. (2015). Sifat Fisikokimia dan Organoleptik Tepung Mocaf (Modified 
Cassava Flour) Dengan Fermentasi Menggunakan Ekstrak Kubis. The 2nd University Research Coloquium, 10-17.

Koswara, S. (2009). Teknologi Pengolahan Singkong (Teori Dan Praktek). Teknologi Pengolahan Singkong, 1-24.

Noor, Z., Cahyanto, M. N., Indrati, R., \& Sardjono, S. (2018). Skrining Lactobacillus plantarum Penghasil Asam Laktat untuk Fermentasi Mocaf. Agritech, 37(4), 437. https://doi. org/10.22146/agritech.18821

Nur'utami, D. A., Fitrilia, T., \& Oktavia, D. (2020). Pengaruh Lama Fermentasi terhadap Karakteristik Sensori dan Daya Kembang Roti Mocaf (Modified Cassava Flour). Jurnal Agroindustri Halal, 6(2), 197. https://doi. org/10.30997/jah.v6i2.3255

Putri, N. A., Herlina, H., \& Subagio, A. (2018). Karakteristik Mocaf (Modified Cassava Flour) Berdasarkan Metode Penggilingan Dan Lama Fermentasi. Jurnal Agroteknologi, 12(01), 79. https://doi.org/10.19184/j-agt. v12i1.8252
Rosmeri, V. I., \& Monica, B. N. (2013). Pemanfaatan Tepung Umbi Gadung (Dioscorea hispida Dennst) dan Tepung MOCAF (Modified Cassava Flour) Sebagai Bahan Substitusi dalam Pembuatan Mie Basah, Mie Kering, dan Mie Instan. Jurnal Teknologi Kimia Dan Industri, 2(2), 246-256.

Tandrianto, J., Mintoko, D. K., \& Gunawan, S. (2014). Pengaruh Fermentasi pada Pembuatan Mocaf (Modified Cassava Flour) dengan Menggunakan lactobacillus plantarum terhadap Kandungan Protein. Jurnal Teknik Pomits, 3(2), 143-145.

Unayah, A., Estuti, W., Kunaepah, U., Studies, N., Tasikmalaya, P. K., \& Barat, J. (2020). Use of Local Food Ingredients MOCAF (Modified Cassava Flour) and Rebon Planktonic Shrimp) in Cookies as an Alternative Supplementary Food for Children. International Journal of Innovation, Creativity and Change, 10351050. 